\title{
Landuse Types within Channel Corridor and River Channel Mor- phology of River Ona, Ibadan, Nigeria
}

\author{
Olutoyin A. Fashae, Adeyemi O. Olusola
}

Received: September 2016/ Accepted: January 2017 / Published online: December 2017

๑) 2017 Faculty of Geography UGM and The Indonesian Geographers Association

\begin{abstract}
Studies involving river corridor needs a clear cut and an integrated basin management approach because it helps in improving or maintaining water quality, protecting wetlands, enhancing river restoration decision etc. Hence, this study seeks to identify major landuse types within the River Ona Corridor; examine the impact of these landuse types within the River Ona corridor on its channel morphology and understand the risk being posed by these landuse types. The study is designed by selecting two reaches of six times the average width from each of the four major landuse types that exist along the river corridor. This study revealed that along the downstream section of Eleyele Dam of River Ona, natural forest stabilizes river channel banks, thereby presenting a narrow and shallow width and depth respectively but the widest of all is found within the agricultural zones.
\end{abstract}

Keywords: River Corridor, Risk, Landuse, River Ona, Channel morphology

\begin{abstract}
Studi yang melibatkan koridor sungai memerlukan pemangkasan yang jelas dan pendekatan pengelolaan lembah terpadu karena membantu memperbaiki atau mempertahankan kualitas air, melindungi lahan basah, meningkatkan keputusan restorasi sungai, dan lain-lain. Oleh karena itu, penelitian ini bertujuan untuk mengidentifikasi jenis penggunaan lahan utama di dalam Sungai Ona Corridor; memeriksa dampak dari jenis penggunaan lahan di koridor River Ona pada morfologi salurannya dan memahami risiko yang ditimbulkan oleh jenis penggunaan lahan ini. Penelitian ini dirancang dengan memilih dua rangkap enam kali lebar rata-rata dari masing-masing dari empat jenis penggunaan lahan utama yang ada di sepanjang koridor sungai. Studi ini mengungkapkan bahwa di sepanjang bagian hilir Bendungan Eleyele Sungai Ona, hutan alam menstabilkan bank saluran sungai, sehingga menghadirkan lebar dan kedalaman yang sempit dan dangkal namun paling luas ditemukan di dalam zona pertanian.
\end{abstract}

Kata kunci: Koridor Sungai, Risiko, Penggunaan Lahan, Ona Sungai, Morfologi Saluran

\section{Introduction}

The land abutting river channels are very essential to aquatics and terrestrial ecosystems [Allen, 1995; Smith et al., 2008], they are needed for important ecosystem services [Postel and Carpenter, 1997], and are collectively important [Millennium Ecosystem Assessment, 2005]. These areas are referred to as channel corridors. Fluvial studies have shown that river corridors are being established to maintain natural channel form and functions, as well as essential ecosystem services such as flood and erosion hazard mitigation. River channel corridors have been defined by Kline [2008] as the total river corridor width equal to eight reference channel widths drawn, using four reference channel widths on either side of the mean der center - line or extended laterally eight reference channel widths out from the valley toe. River corridors are established as the most likely area where channel

Olutoyin A. Fashae

Department of Geography, University of Ibadan, Ibadan, Nigeria

Adeyemi O. Olusola

Department of Geography, University of Ibadan, Ibadan, Nigeria

Correspondent email: toyinafashae@yahoo.com adjustments may occur, equilibrium condition may be come re-established, and the minimization of work (i.e., erosion) takes place [Leopold, 1994]. It is possible ssible that channels will migrate outside of adelineated river corridor due to extreme events such as channel avulsions due to large floods or landslides. Leaving the river corridor unprotected or unplanned for invites future encroachments in high risk locations and misses the opportunity to provide enough space for stream processes and equilibrium to occur. Once people build or carry out unchecked activities within the corridor, it is compromised and of great danger. The importance of river corridors therefore presents a clear cut and an integratedbasin management approach since it is of great importance as regards improving or maintaining water quality, protecting wetlands, enhancing river restoration designs, maintaining natural hydrological processes, maintaining riparian vegetation, providing water supply and navigation, enhancing fish and wildlife habitat, improving recreation opportunities, and encouraging compatible economic development.

The landuse types within the channel corridor significantly affect the behavior and response of river 
channels [Wolman, 1967; Schumm et al., 1984]. Simons et al [1981] emphasized that river response to landuse within channel corridor may be slow or rapid based on the level of anthropogenic activities within such landuse types. Based on their report, when a river channel is modified due to changes in the use of a channel corridor there is usually a response in form of induced alteration in channel morphology both up and downstream irrespective of the measures to control the river environment. Clark and Wilcock [2000], in their study on the effects of land-use change on channel morphology in northeastern Puerto Rico, observed that between 1830 and 1950 when much of the corridor was cleared for agriculture, runoff increased approximately by $50 \%$ and sediment supply to the river channels also increased. Olusola [2012] also observed that there is a significant change in channel process as a result of alteration within channel corridors. Due to the unchecked increase in urbanization especially in major cities of most Third World countries, rivers have been responding in various ways to the increase in urban population. Hence, the reason why most of the studies carried out on urban rivers have been concerned with the impact of urbanization on river channel morphology [e.g. Klein, 1979; Arnold et al., 1982; Ebisimiju, 1989a,b; Odemerho,1992; Booth and Jackson, 1997; Trimble, 1997; Jeje and Ikezeato, 2002; Nilsson et al., 2003; Fashae, 2011; Olusola, 2012] while very few ones consider the importance of channel corridors. This study therefore seeks to provide an understanding on the impact of various landuse types on river corridor. To achieve this, the following specific objectives are considered: to identify major landuse types within the River Ona Corridor; examine the impact of these landuse within the River Ona channel corridor on its channel morphology and understand the risk being posed by these landuse types. River Ona is very appropriate for this study due to the following observed reasons: high level of urbanization within the basin, increase in human activities such as grazing along the river corridor, discharge of industrial effluents, dumping of solid wastes in the river and construction of buildings close to the river and more importantly the different landuse types and their transition along various sections of the river corridor (natural forest, residential, commercial, agricultural) from its upstream section below the Eleyele dam to its downstream section where it captures River Ogunpa.

River Ona is a perennial fifth order stream using the Strahlers' stream ordering system. It traverses the city of Ibadan, Nigeria in the north-south direction and it lies on the basement complex rock types of the humid tropical environment (Figure 1).

The major rock types in the study area are quartzite, quart schist of the metasedimentary series, banded gneisses, augen gneisses and migmatites. The climate is under the influence of two air masses: the wet tropical maritime and the dry tropical continental. As a result of this, the area is marked with alternating wet and dry seasons. The wet season is characterized by high rainfall between April and October with double

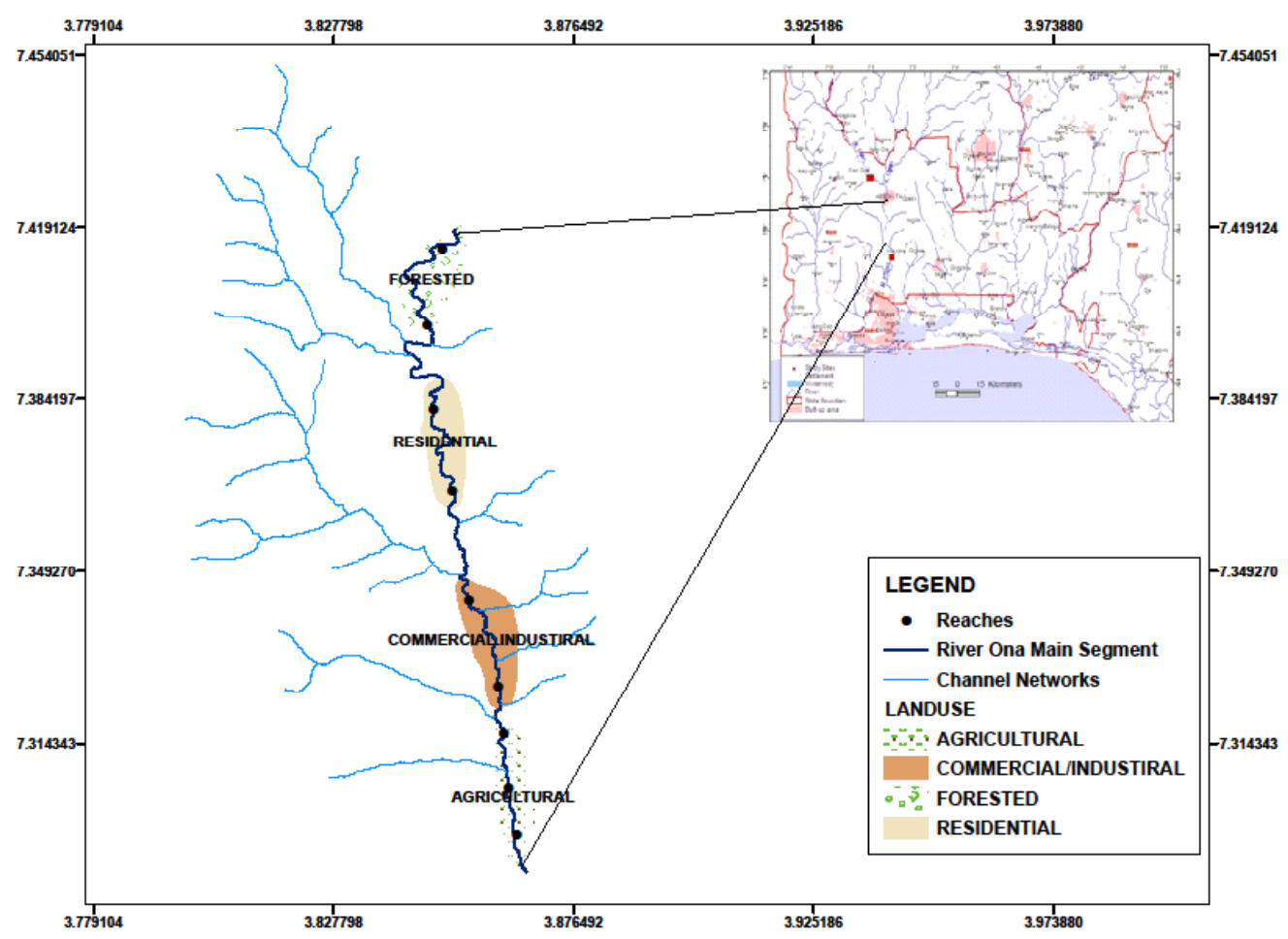

Figure 1. Map showing the landuse types along River Ona channel corridor 
peaks and in between the two peaks is a break known as 'August break'. The wet humid climate encourages the occurrence of highly weathered rocks. The weathering profile shows that the original rocks had been weathered to considerable depth forming thick weathering crust with thick overburden overlying the weathered and under weathered bedrocks [Faniran, 1970]. The weathered mantle, regolith and saprolite store water and act as good aquifer. The mean annual temperature is about $26^{\circ} \mathrm{C}$ with the hottest month in March which precedes the beginning of the wet season. The climax vegetation is tropical rain forest. Hopkins [1965] classified the vegetation under moist semi-deciduous rain forest. Soils are oxisols using US soil classification system. They are highly weathered and leached. They are formed in the humid tropical environment under vegetation cover. However, as a result of urban growth, agricultural and other human activities, the climax vegetation has been depleted, giving rise to secondary forest. Some plant species found along the corridors of River Ona are Penicum maximum, Cynodon dactylon, Setara babata, Oplismenus burmanis, Eleusine indica, Sacciolepsis africana, Physalis spp. Etc.

\section{The Methods}

The study is designed by selecting two reaches of six times the average width [Wohl, 1998] from each of the four major landuse types that exist along the river corridor. The extent of the river corridor is adopted from Kline 2008 which states that the total river corridor width would be equal to eight reference channel widths. The reaches were divided into cross-sections for adequate measurements of channel parameters-average channel width $(\mathrm{m})$ and depth $(\mathrm{m})$. The average channel width and depth was measured using a measuring tape and graduated pole respectively, while the other parameters were derived from the measured parameters - crosssectional area (m sq.) and width-depth ratio (-).

Estimate of vegetation cover was done at each cross-section by sampling the riparian vegetation at the river banks (Hupp et al., 1996). The sampling was performed along $5 \mathrm{~m}$ transect beginning at the crosssection and progressing upstream. The percentage (\%) vegetal cover was estimated and averaged for each landuse type. The main vegetal cover parameters that are of concern for this study are percentage (\%) cover of trees and percentage (\%) cover of shrubs as these are the dominant vegetal life-forms along the river corridor.

\section{Results and Discussion \\ Reach Morphology}

The mean of each of the measured and derived channel parameters (Figure 2) across the various landuse types was presented on a composite bar graph. Channel width clearly reveals that natural forest has the smallest channel width (Figure 2 and 3) as compared to other landuse types and the widest width was found within the agricultural land-use. The graph shows that the agricultural corridor has the widest channel width, closely followed by commercial corridor. The agricultural section of this river channel has been known for extensive cattle grazing and the result obtained here is in tandem with some other results revealing increased river channel widening (Table 1) along grazed corridors [Trimble and Mendel, 1995; Trimble, 1997].

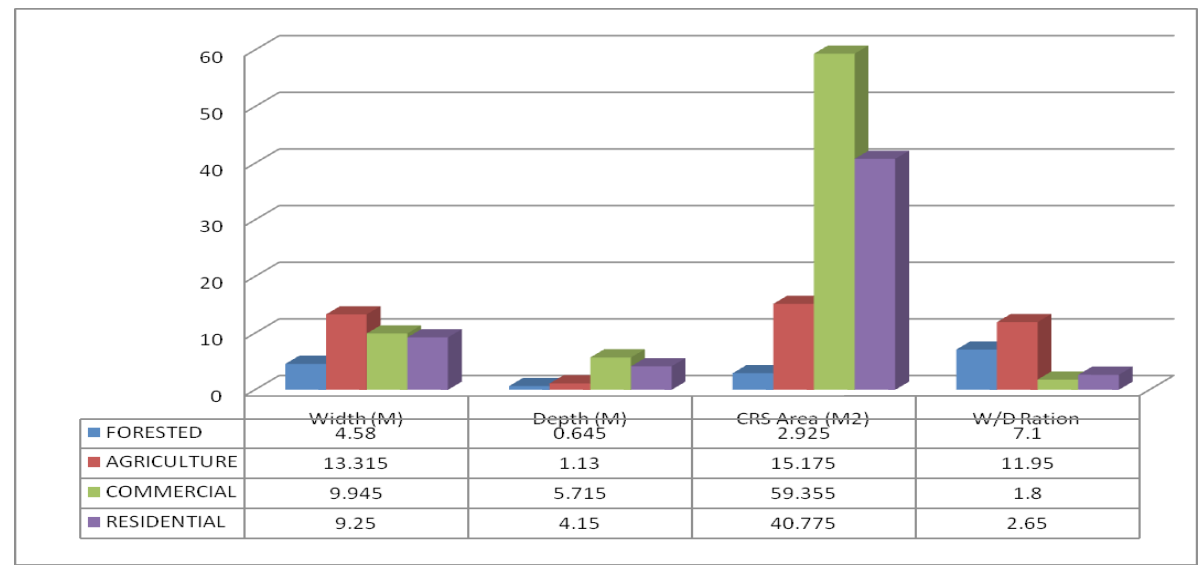

Figure 2. Bar graph showing channel parameters across the various landuse types along the channel corridor

Several studies have been able to show that natural forest helps in binding channel width (Table 1) and provide support for channel stability [Thorne, 1990; Rowntree and Dollar, 1999; Millar, 2000; Strahler and Strahler, 2005] than non-vegetated areas. In the same vein, it has been established that as urbanization increases, an important aspect of commercial and urban areas, the river responds positively by increasing its channel width to adjust appropriately for increase in discharge [Jeje and Ikezeato; 2002, Olusola, 2012]. 


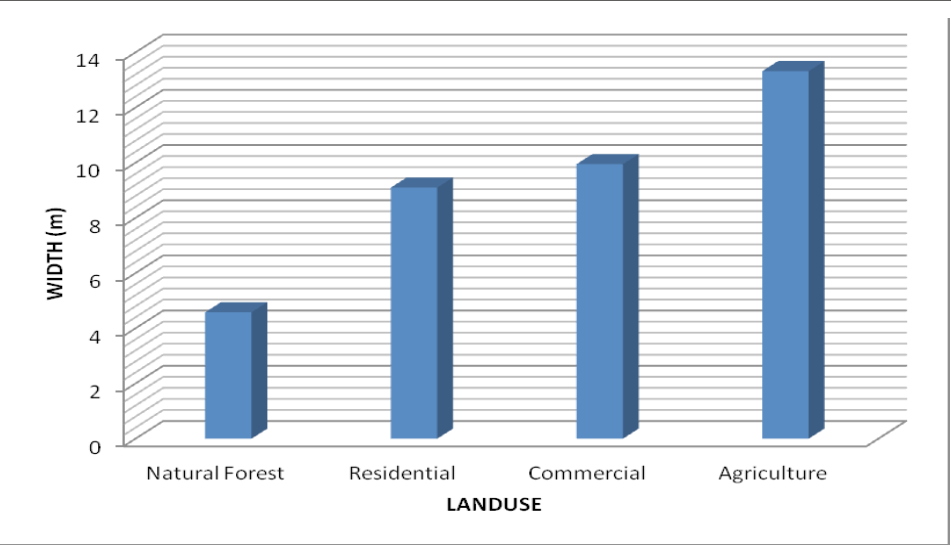

Figure 3. Graph showing variation in channel width along various landuse types.

The variation in depth along the downstream section of the river channel reveals a gradual increase in channel depth as the river flows from the natural forest into the urbanized areas (residential and commercial) and drops again in dimension within the agricultural land-use type (Figure 2 and 4). The deepest part of the river channel is found within the commercial and the residential corridor. The reason for this is tied to the fact that forested and agricultural reaches have sediments that are constantly washed into the river channel and these result in silting of the channel bed [Trimble, 1997].

Table 1. Vegetal cover across the River Ona corridor

\begin{tabular}{lccc}
\hline \multicolumn{1}{c}{ Land-use } & \% Trees & \% Shrubs & Width-depth ratio \\
\hline Forested & 79.60 & 37.5 & 7.1 \\
Residential & 7.30 & 25 & 11.95 \\
Commercial & 1.8 & 25 & 1.8 \\
Agriculture & 11.19 & 12.5 & 2.65 \\
\hline
\end{tabular}

Source: Author’s Fieldwork

Although, some studies reveal that forested areas are deeper while non-forested areas are shallower, but as it stands in this study, the deepest sections of the river channel are found within the residential and commercial corridor, which is due to the incision of the river fow in its channel bed as a result of urbanization Ebisemiju, [2009; Olusola, 2012].

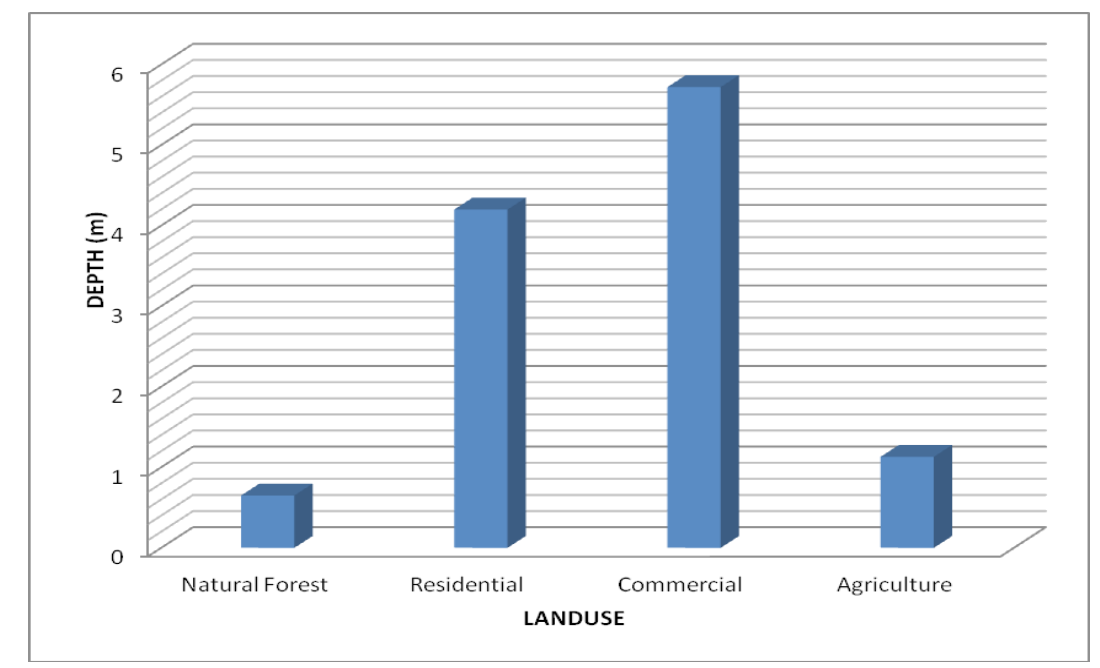

Figure 4. Graph showing variation in channel depth along various landuse types. 


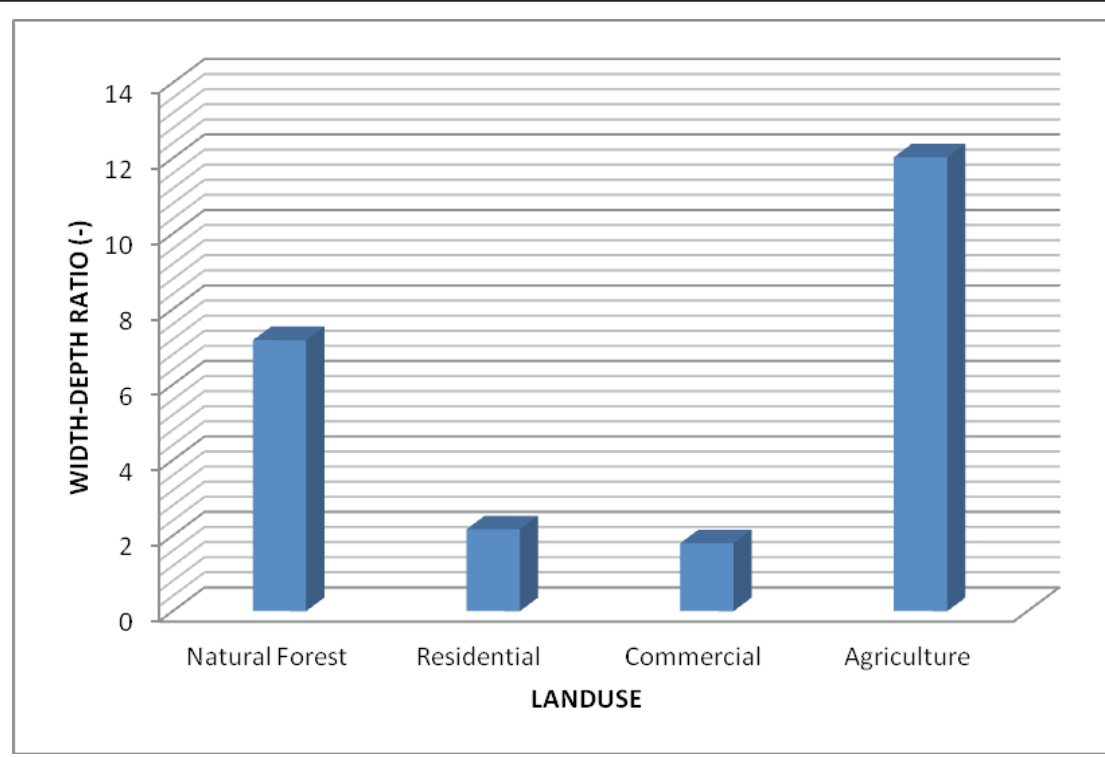

Figure 5. Graph showing variation in channel width-depth ratio along various landuse types.

Width-depth ratio is a dimensionless measure that shows the relationship between average width and average depth (Table 1). The variation in width-depth ratio within the four corridors reveals that agricultural section has the highest with-depth ratio (Figure 2 and 5). The increase in width-depth ratio within the agricultural section is due to heavy grazing which has initially widened the channel considerably [Trimble, 1997]. The impact of free grazing animals has been linked to increase in channel width [Trimble, 1997; Dufour, 2015]. This suggests that the channel efficiency is at its maximum here within the agricultural section as it can accommodate increase in volume of discharge within this section [Olusola, 2012].

To understand if significantly landuse types within channel corridor alter channel morphology, analysis of variance (ANOVA) was performed. ANOVA (Table 2) revealed that variation in different human activities along the channel corridor explains the differences in the dimensions of the morphologic variables $(\mathrm{P} \leq 0.01)$.

Table 2. Analysis of Variance

\begin{tabular}{lcc}
\hline \multicolumn{1}{c}{ Morphologic Variables } & $\mathrm{F}$ & $\mathrm{P}$ \\
\hline Width (M) & 15.463 & $.011^{\star}$ \\
Depth (M) & 9.406 & $.028^{\star}$ \\
W/D Ratio & 25.433 & $.005^{\star}$ \\
\hline
\end{tabular}

*Significant at 0.05

Although conflicting views still exist as to why rivers are wide or narrow at some sections and shallow or deep at others. This study has shown that even within river corridors, certain activities alter significantly channel dimensions. The importance of channel corridor cannot be overemphasized because it is the minimum area that is able to contain a major flood and pass water safely to the sea. Therefore, unplanned and unprotected channel corridor can be a threat to properties, structures and human livelihood. Construction of buildings and commercial structures within the River Ona channel corridor poses a great risk to properties, structures and human livelihood. Width-depth ratio (w/d ratio), a form factor, which measures channel efficiency, is considered low if it is less than 12 and this suggests a very narrow width and deep depth. Low width-depth ratio poses potential threat to structures and properties that have violated the minimum setback along channel corridors. Areas with very deep and relatively narrow width are fast flowing and gives rise to a particular set of adverse flooding effects. They include the production of debris from damaged structures and vegetation, the movement of debris and creation of debris dams, and the potential diversion of flood water due to obstacles in the path of the moving water. These effects can produce a number of significant impacts such as a threat to the security of the flood defence system and the integrity of bridges, damages to structures, and a general threat to life including a high propensity for social disruption.

\section{Conclusion}

Various studies have reported the effect of development due to increase in concretization on river channel morphology [Booth and Jackson, 1997; Trimble, 1997; Jeje and Ikezeato, 2002; Nilsson et al., 2003]. Others have shown different ways by which riparian vegetation affects river channel morphology [Thorne; 1990]. As it relates to other studies, this study has revealed the impact of landuse within river channel corridor on channel morphology. Although existing literature are quite few in this clime as to how 
channel corridor impacts channel width and depth, this study has revealed that along the downstream section of Eleyele Dam of River Ona, natural forest stabilizes river channel banks, thereby presenting a narrow and shallow width and depth respectively [Huang and Nanson, 1997]. The widening of river channel has often times been attributed to increase in urbanization, but this study also clearly reveals that although within urbanized zones, river channel width is quite wide, but the widest of all is found at the agricultural zones. The reason for this, among other things, has been tied to the heavy grazing along the river channel corridor around these sites [Trimble, 2007].

As revealed by the analysis of variance, activity along the channel corridor significantly affects the channel dimensions. Therefore, channel corridors are equally important in the understanding of instream process and channel morphology. The observed impact of landuse types within the channel corridor has been shown to pose a great risk to human lives and properties. Hence, it is expected that channel corridors are either cordoned off or earmarked for grazing reserves and limited human activities should be permitted.

\section{References}

Allen, J.D., (1995). Stream ecology structure and function of running waters. Formerly published by Chapman and Hall now published by Kluwer Academic Publishers, Dordrecht, The Netherlands.

Arnold, C.L., Boison, P.J., Patton, P.C., (1982). Sawmill Brook: and example of rapid geomorphic change related to urbanization. Journal of Geology 90, 155-166.

Booth DB Jackson CR (1997). Urbanization of aquatic systems: degradation thresholds, storm water detention, and the limits of mitigation. Journal of the American Water Resources Association 33, 1077-1090.

Clark, J.J., and Wilcock, P.R. (2000). Effects of land-use change on Channel Morphology in North-Eastern Puerto Rico.GSA Bulletin.V112: No 122.

Dufour, S., Massimo, R., Herve, P. and Amael, M (2015). How do rivers dynamics and human influences affect the landscape pattern of fluvial corridors? Lessons from Magra River, Central-Northenr Italy. Landscape and Urban Planning. 134: 107118.

Ebisemiju, F. S. (1989). The morphology and downstream hydraulic geometry of alluvial stream channels in a Humid Tropical Environment, South-western Nigeria. J. Hydrol. 142:319-335. Geografiska Annalar, Vol. 49A pp. 385-395.

Ebisemiju F S (1989). Patterns of stream channel response to urbanization in the humid tropics and their implications for urban land use planning: a case study from southwestern Nigeria, Applied Geography, 9, 273-286.

Faniran, A (1970). Landform Examples from Nigeria No. 2, The Deep Weathering (Duricrust) Profile. Nig. Geog. Journal, Vol. 13, No. 1, pp. 87-88.

Fashae O. (2011). Impact of Riparian Vegetation on Lower Ogun River Channel. Unpubl.Ph.D.Thesis, University of Ibadan.

Hey, R.D. and Thorne, C.R. (1986). Stable Channels with Mobile Gravel Beds. ASCE, J. Hydraulic Engineering112 (6): 671-689.

Hopkins, B. (1965). Forest and Savanna. Heineman, Ibadan.

Hupp C.R. and Osterkamp W.R.(1996). Geomorphology. Vol 14, Issue 4, Pages 277-295.

Huang H.Q. and Nanson, G.C.(1997). Vegetation and Channel Variation, A case study of four Small Streams in South-Eastern Australia. Geomorphology 18:237-249.

Jeje, L.K. Ikeazota, SI (2002). Effects of Urbanization on Channel Morphology: The Case of Ekulu River in Enugu, Southeastern Nigeria. Singapore Journal of Tropical Geography 23 (1), 37-51

Kline, M., (2008). Vermont ANR Guide to River Corridor Protection. Vermont Agency of Natural Resources, Waterbury, Vermont. http://www. vtwaterquality.org/rivers/htm.

Leopold, L.B., (1994). A View of the River. Harvard University Press, Cambridge, Massachusetts.

Malkinson, D. and Wittenberg, L. (2007). Scaling the Effects of Riparian Vegetation on Cross-sectional Characteristics of Ephemeral Mountain Streams-A Case Study of Nahal Oren, Mt. Carmel, Isreal. Catena 69:103-110.

Millar, R.G. (2000). Influence of Bank Vegetation on Alluvial Channel Patterns. Water Resource Res. 36: 1109-1118 Resources Publications Littleton, Colorado, 20pp.

Millennium Ecosystem Assessment (2005). Ecosystems and Human Well-Being: Wetlands and Water Synthesis. World Resource Institute, Washington, D.C.

Nilsson, C., Pizzuto, J.E., Moglen, G.E., Palmer, M.A., Stanley, E.H., Bockstael, N.E., Thompson, L.C., (2003). Ecological forecasting and the urbanization of stream ecosystems: challenges for economists, hydrologists, geomorphologists, and ecologists. Ecosystems 6 (7), 659-674.

Odemerho, F. O. (1992). Limited downstream response of stream channel size to urbanization in a humid tropical basin. Professional Geographer, 44(3): 322-339. 
Olusola, A.O. (2012). Downstream variation in stream power of Ona River below Eleyele Dam Unpubl M.Sc Dissertation, Department of Geography, University of Ibadan.

Postel, S. and S. Carpenter, (1997). Freshwater Ecosystem Services. In: Nature's Services, Gretchen Daily (Editor). Island Press, Washington, D.C., pp. 195-214.

Rowntree, K.M. and Dollar, E.S.J. (1999). Vegetation controls on channel stability in the Bell River, Eastern Cape, South Africa. Earth Surface, processes and landforms 24,127-134.

Schumm, et al. (1984). Incised channels: Morphology, dynamic and control. WaterResources Publications.

Simon et al. (1981). Drainage and flood control.

Smith, M.P., R. Schiff, and J. Opperman, (2008). Riparian Zones: They aren't just for buffers any more. Water Resources IMPACT 10(3):6-8.

Strahler and Strahler (2005). Physical Geography. John Wiley and Sons.

Thorne, C.R., (1990). The Effects of Vegetation on Riverbank Erosion and Stability. In: Thorne, C.R. (Ed), Vegetation and Erosion. Wiley, Chichester, pp.125-144.

Trimble, S. W. (1997). Stream Channel Erosion and Change Resulting from Riparian Forests. Geology. 25(5):467-469.

Trimble, S.W. and Mendel, A.C. (1995). The Cow as Geomorphic Agent: A Critical Review: Geomorphology, vol. 13(1-4), pp. 233-253.

Wolman, M.G., (1967). A cycle of sedimentation and erosion in urban river channels: Geografiska Annalar, v. 49A,p. 385-395.

Wohl, E. E., (1998). Bedrock channel morphology in relation to erosional processes, in Rivers over Rock: Fluvial Processes in Bedrock Channels, edited by K. J. Tinkler, and E. E. Wohl, pp. 133151, Am. Geophys. Union, Geophys. Mono. 107, Washington D. C. 